\title{
INTIMATE INTEGRATION
}


STUDIES IN GENDER AND HISTORY

General Editors: Franca Iacovetta and Karen Dubinsky 


\title{
Intimate Integration
}

\section{A History of the Sixties Scoop and the Colonization of Indigenous Kinship}

\author{
ALLYSON D. STEVENSON
}

UNIVERSITY OF TORONTO PRESS

Toronto Buffalo London 
(C) University of Toronto Press 2021

Toronto Buffalo London

utorontopress.com

Printed in Canada

\begin{abstract}
ISBN 978-1-4875-0064-1 (cloth) ISBN 978-1-4875-1152-4 (EPUB)
ISBN 978-1-4875-2045-8 (paper) ＩSBN 978-1-4875-1151-7 (PDF)
\end{abstract}

\title{
Library and Archives Canada Cataloguing in Publication
}

Title: Intimate integration : a history of the Sixties Scoop

and the colonization of Indigenous kinship / Allyson D. Stevenson.

Names: Stevenson, Allyson D., 1976- author.

Series: Studies in gender and history ; 51 .

Description: Series statement: Studies in gender and history ; 51 ।

Includes bibliographical references and index.

Identifiers: Canadiana (print) 20200195956 ।

Canadiana (ebook) 20200196006 | ISBN 9781487500641 (cloth) |

ISBN 9781487520458 (paper) | ISBN 9781487511524 (EPUB) |

ISBN 9781487511517 (PDF)

Subjects: LCSH: Canada. Indian Act. I LCSH: Interracial adoption - Canada. I

LCSH: Child welfare - Canada. I CSH: Native children - Canada - Social conditions. I CSH: Native peoples - Kinship - Canada. I CSH: Native peoples - Relocation -

Canada. I CSH: Native peoples - Canada - Government relations.

Classification: LCC HV875.7.C2 S74 2020 I DDC 362.734089/97071-dc23

Cover illustration: Maashkowishiiw She is strong, Sherry Farrell Racette, 2015, acrylic on canvas. A story painted from a story told of a story heard - a child's memory through an elder's voice - a woman's courage as she faces aggressive men who threaten her family. She flees up into the hills and watches as her house burns. She makes her way to Manitoba where she rebuilds and raises her children. Not a victim. A warrior-mother. This painting is from the project From Here: Story Gatherings from Regina and the Qu'Appelle Valley, a series of paintings based on conversations with Métis elders, commissioned by the Gabriel Dumont Institute.

This book has been published with the help of a grant from the Federation for the Humanities and Social Sciences, through the Awards to Scholarly

Publications Program, using funds provided by the Social Sciences and Humanities Research Council of Canada.

University of Toronto Press acknowledges the financial assistance to its publishing program of the Canada Council for the Arts and the Ontario Arts Council, an agency of the Government of Ontario.

\section{Canada Council for the Arts}

Conseil des Arts du Canada

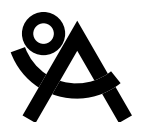

ONTARIO ARTS COUNCIL CONSEIL DES ARTS DE L'ONTARIO

an Ontario government agency un organisme du gouvernement de I'Ontario $\begin{array}{rr}\begin{array}{r}\text { Funded by the } \\ \text { Government } \\ \text { of Canada }\end{array} & \begin{array}{r}\text { Founernement par le } \\ \text { du Canada }\end{array}\end{array}$

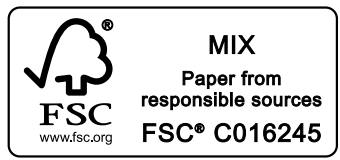

